\title{
The Effect of Halopriming and Salicylic Acid on the Germination of Fenugreek (Trigonella foenum-graecum) under Different Cadmium Concentrations
}

\author{
Arezoo ESPANANY, Seyfollah FALLAH*, Ali TADAYYON
}

Shahrekord University, Faculty of Agriculture, Department of Agronomy, POBox 115, Shahrekord, Iran; falah1357@yahoo.com ("correspondingauthor)

\begin{abstract}
The hereby study was based on a factorial experiment conducted in a completely randomized design with four replications, at Agriculture College, Shahrekord University, Iran, in 2014. The role of salicylic acid (SA), potassium nitrate $\left(\mathrm{KNO}_{3}\right)$ and potassium chloride $(\mathrm{KCl})$ was evaluated on seed germination of fenugreek (Trigonella foenum-graecum L.) under different cadmium concentrations. Treatments included four levels of seed priming (no priming, potassium chloride, potassium nitrate, salicylic acid) and four levels of cadmium concentration $(0,10,20,30 \mathrm{mg} / \mathrm{L})$. Cadmium chloride caused a significant inhibition in germination percentage, root elongation, shoot elongation and seedling dry weight. The shoot length was more sensitive to cadmium concentrations than the root length. Primed seeds with SA $(100 \mathrm{mg} / \mathrm{L})$ proved protection against $\mathrm{Cd}$ stress and increased the germination percentage, root elongation, shoot elongation and dry weight of seedlings compared to the control treatment. Seeds treated with SA alleviated the Cd negative effect on germination parameters. In conclusion, using seed priming with salicylic acid can be recommended as a good technique for fenugreek crop on fields exposed to high cadmium toxicity.
\end{abstract}

Keywords: heavy metal, seedling, seed priming, root, vigor

\section{Introduction}

Cadmium (Cd) is a highly toxic heavy metal, representing an environmental concern, because of its low mobility in soils (D'Souza et al., 2008). It can be accumulated in soil through agricultural application of sewage sludge, fertilizers, and/or through land disposal of Cd-contaminated municipal and industrial wastes (D'Souza et al., 2008). Cd causes oxidative stress (Mudipalli, 2008) by formation of free radicals. Oxidative stress refers to enhanced generation of reactive oxygen species (ROS), that may result from alterations of numerous physiological processes caused at cellular/molecular level by inactivating enzymes, blocking functional groups of metabolically important molecules ( $\mathrm{La}$ Rocca et al., 2009); it can also overwhelm cell's intrinsic antioxidant defense and can lead to cell damage or plant death (Krystofova et al., 2009) and disrupting membrane integrity (La Rocca et al., 2009).

Cadmium competes with iron, manganese, zinc, copper, calcium, magnesium and potassium (Liu et al., 2003), therefore this metal has high priority for removal from aqueous environments (Rama et al., 2002).

Cadmium toxicity alters the morphological, physiological, biochemical and structural processes of plants, including inhibition of germination and seedling growth (Mishra et al., 2006). After long-term exposure to $\mathrm{Cd}$, roots become mucilaginous, browning, and decomposing; therefore, a reduction of shoots can be observed, along with root elongation. Cd was found to inhibit lateral root formation, while the main root became brown, rigid and twisted (Rascio and Navari-Izzo, 2011). The main reason indicated was disorder of cell division and abnormal enlargement of epidermis and cortical cell layers in the apical region (Liu $e t$ al., 2010).

The plant root is the first area affected by cadmium, so the reaction with root cells leads to changes in the physiological properties of cell plasma membranes, having high ability to cross cell membranes rooted (Astolfi et al., 2003).

Fenugreek (Trigonella foenum-graecum L.) belongs to Leguminosae (Fabaceae) family (Kaviarasan et al., 2007). This is a native crop extending from Iran to northern India (Petropoulos, 2002) and it is commonly used as a condiment in food preparation for its nutritive and restorative properties. It was also known and used in folk medicine for centuries for a wide range of diseases including diabetes (Eidie et al., 2007).

Stand establishment is of primary importance for optimizing field production of any crop plant. At sub-optimal environmental conditions, poor seed germination and subsequently poor field establishment is a common phenomenon (Mwale et al., 2003). Seed priming is a presowing strategy for influencing seed germination and seedlings' development by modulating germination metabolic activity prior to emergence of the radical, and generally enhances germination rate and plant performance (Bradford, 1986). This technique changes the pattern of $\mathrm{N}$ and $\mathrm{Ca}^{+2}$ 
homeostasis, both of the seeds and seedlings; these modifications were associated with enhanced $\alpha$-amylase activity and the content of reducing sugars. Positive correlation of seedling attributes with the nutrient content suggested that, as a result of seed priming, most $\mathrm{N}$ and $\mathrm{Ca}^{+2}$ were partitioned to the embryo, enhancing seedling emergence and subsequent growth of rice seedling (Farooq et al., 2010).

Applying priming treatments improved the antioxidant activity of treated seeds (Wang et al., 2003). Priming can facilitate the growth of the embryo before germination, subsequent embryo development and improves germination and emergence after planting under normal, as well as stress, conditions (Neamatollahi et al., 2009). The researchers also expressed uniform seedlings from seed osmo-priming, which is supposed to be due to a more uniform and more rapid synthesis of proteins (El-Araby and Hegazi, 2004).

Salicylic acid (SA) is involved on membrane permeability, absorption of ions and prevention of both biotic (Alvarez, 2000) and abiotic stresses (Tissa et al., 2000). It can affect the accumulation of heavy metals, as observed in pea plants for which soaking of seeds in SA resulted in reduced accumulation of Cd in plants (Popova et al., 2009).

Cadmium induces changes in physiological, biochemical and morphological processes such as oxidative stress, reduction of the germination percentage, reduction in the root length and shoot length and seedling weight. However, progress of industry makes pollution of water sources increasing with heavy metals, such as cadmium, while on the other hand, for farming systems, use of water resources is essential. Germination is known to be one of the most important and most critical steps, influenced by changes in the surrounding environment. The present study was performed to determine the effect of seed priming treatments in reduction of cadmium toxicity on seed germination sensitive plants, like fenugreek seed.

\section{Materials and Methods}

\section{Seedpriming}

In order to evaluate the effect of seed priming on the germination and seedlings' growth traits of fenugreek (Trigonella foenum-graecum L.) under cadmium stress, a factorial experiment was conducted in completely randomized design with four replications, at the Faculty of Agriculture, Shahrekoord University, Iran, in 2014. The fenugreek plants were purchased from Pakan Bazr Company, Isfahan, Iran. Seeds were rinsed with water and distilled water, then surface sterilized in $40 \%$ sodium hypochlorite (vol/vol) for 10 minutes, followed by $70 \%$ alcohol (vol/vol) for 10 seconds; after, were thoroughly rinsed with sterile deionized water and then seeds were primed.

For halopriming, seeds were placed on $-0.3 \mathrm{MPa}$ of potassium nitrate $\left(\mathrm{KNO}_{3}\right)$ and $-0.3 \mathrm{MPa}$ potassium chloride $(\mathrm{KCl})$, while for hormopriming, they were placed on a salicylic acid (SA) solution $(100 \mathrm{mg} / \mathrm{L})$ in the chamber room, under dark condition at $15^{\circ} \mathrm{C}$, for 24 hours. As a next step, seeds were rinsed with distilled deionized water $\left(\mathrm{ddH}_{2} \mathrm{O}\right)$ three times, to wash off the $\mathrm{KNO}_{3}, \mathrm{KCl}$ and SA solutions from their surface, than air dried for 24 hours at $25^{\circ} \mathrm{C}$ to reach the original moisture content $(\sim 12-13 \%)$ and immediately used for germination tests. Unprimed seeds were used as control.
The amount of potassium nitrate required was calculated using the Want hoof equation (Siebert and Richardson, 2002):

$\Psi_{s}=-\operatorname{miRT}$

$\Psi \mathrm{s}=$ Osmotic potential $(\mathrm{MPa})$

$\mathrm{m}=$ Molality of solution (mol dissolved in $1000 \mathrm{~g}$ water) $\mathrm{i}=$ Ion coefficient (equal to 2 for salts dissolved in water)

$\mathrm{R}=$ Fixed amount of gas (00831/0 liter MPa per mol K)

$\mathrm{T}=$ Temperature in degrees Kelvin = temperature in degrees Celsius + 273 .

\section{Germination of seeds under cadmium conditions}

For germination test, unprimed seeds were surface sterilized following the same steps as for primed seeds. A total of 200 seeds (primed and unprimed) in four replicates (50 seeds/replicate) for each treatment, were sown within 9$\mathrm{cm}$-diameter Petri dishes on filter paper soaked with $5 \mathrm{mg} / \mathrm{L}$ $\mathrm{CdCl}_{2}$, at concentrations of $0,10,20$ and $30 \mathrm{mg} / \mathrm{L} \mathrm{CdCl}_{2}$, constituted an experimental unit for all experiments. Seeds were incubated in a seed germinator, at alternate temperatures ranging from $20-30{ }^{\circ} \mathrm{C}$, under dark conditions. Seeds were considered germinated when at least $2 \mathrm{~mm}$ long radicle protruded through the seed coat (ISTA, 2009).

As a final step, after 22 days germination percentage, germination rate, root and shoot length, shoot dry weight (DSW), radicle dry weight (DRW) and vigor index (VI) were recorded to evaluate germination performance. Daily germination percentage was recorded and subjected to statistical analysis. The root and shoot vigor were calculated as the sum of total root length $(\mathrm{cm})$ and shoot length $(\mathrm{cm})$ of all the seedlings of a replicate divided by the number of seedlings. Fresh root and shoot were then placed in a hot air oven $\left(70^{\circ} \mathrm{C}\right.$ for 24 hours) to dry (ISTA, 2009). Root and shoot dry mass were measured with electrical balance.

Germination percentage (GP) was calculated using the Equation 1 (Ikic et al., 2012):

$$
G P=\frac{\text { Total seeds germinated after day } 14}{\text { Total number of planted seeds }}
$$

Germination rate (T50) was defined as days needed to reach $50 \%$ of GP.

Coefficient of velocity of germination (CVG) was calculated using the Equation 2 (Kotowski, 1926):

$$
C V G=\frac{N t}{\sum n t} \times 100
$$

In this regard, $\mathrm{CVG}, \mathrm{N}$ and $\mathrm{n}$ are the speed of germination, total germination at the end of the experiment and germinated seeds at time t, respectively.

The vigor index (VI) was calculated as the product of radicle and shoot length by germination percentage (Abdul-Baki and Anderson, 1973).

Seed vigor index was calculated by the Equation 3 (Kalsa and Abebie, 2012):

$$
V I=\frac{G P \%}{R L(c m)}
$$


324

\section{Statistical analysis}

Normality of data was checked prior to analyzing. Data were analyzed statistically by using analysis of variance with SAS 9.1 software. Data were analyzed by using both one- or two-way analysis of variance (ANOVA) and mean comparisons were performed by LSD test; F-test was calculated $(p<0.05)$ to determine whether differences among means were significant between treatments within halopriming, hormopriming and cadmium stress respectively.

\section{Results}

\section{Germination percentage}

Analysis of variance in this experiment showed that seed priming, cadmium concentration and interaction between priming and cadmium concentration had significant effects $(\mathrm{p} \geq$ 0.01 ) on the germination percentage, germination rate, root length and shoot length (Table 1). Germination percentage was significantly decreased with increasing the concentrations of cadmium compared to control treatment. Exposure to $30 \mathrm{mg} / \mathrm{L}$ of cadmium, salicylic acid, potassium nitrate and potassium chloride caused an increase of the germination percentage by $4.16,1.04$ and $2.08 \%$, respectively compared with the control. $\mathrm{KCl}$ and $\mathrm{KNO}_{3}$ showed significant difference with the control, not being phenotypically noticeable though. The highest germination percentage was obtained for primed seeds with 100 $\mathrm{mg} / \mathrm{L} \mathrm{SA}$ in all cadmium concentrations compared to other treatments. The lowest germination was observed in the control treatment using $30 \mathrm{mg} / \mathrm{L}$ cadmium (Fig. 1). $\mathrm{KNO}_{3}$ treatment had no significant difference with control treatment in cadmium concentration $10 \mathrm{mg} / \mathrm{L}$, while $0 \mathrm{mg} / \mathrm{L} \mathrm{Cd}$ concentration had

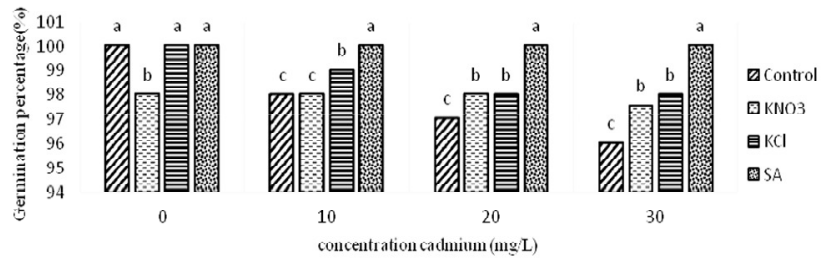

Fig. 1. Germination percentage of unprimed (UPS) and primed (PS) seedlings of fenugreek (Trigonella foenumgraecum $\mathrm{L}$.) under different $\mathrm{Cd}$ concentrations

Germination percentage was measured in unprimed seeds and when seeds were primed by $100 \mathrm{mg} / \mathrm{L} \mathrm{SA}$ and $-1 \mathrm{MPa}^{\mathrm{KNO}} 3$ and $\mathrm{KCl}$ solution for 24 hours. The unprimed seeds were used as the control. Means with similar letters are not significantly different $(\mathrm{p} \leq 0.05)$ based on LSD test.

Table 1. Analysis of variance (mean square) for the effects of seed priming on the germination rate, germination percentage, shoot length and root length, of fenugreek seeds under different cadmium concentrations

\begin{tabular}{cccccc}
\hline $\begin{array}{c}\text { Source of } \\
\text { variance }\end{array}$ & Df & $\begin{array}{c}\text { Germination } \\
\text { percentage }\end{array}$ & $\begin{array}{c}\text { Germination } \\
\text { rate }\end{array}$ & $\begin{array}{c}\text { Shoot } \\
\text { length }\end{array}$ & $\begin{array}{c}\text { Root } \\
\text { length }\end{array}$ \\
\hline $\begin{array}{c}\text { Seed } \\
\text { priming } \\
(\mathrm{P})\end{array}$ & 3 & $17.22^{* *}$ & $2211.9^{* *}$ & $9.62^{* *}$ & $32.15^{* *}$ \\
$\begin{array}{c}\text { Cadmium } \\
(\mathrm{Cd})\end{array}$ & 3 & $7.89^{* *}$ & $46.46^{* *}$ & $12.30^{* *}$ & $8.33^{* *}$ \\
$\mathrm{P} \times \mathrm{Cd}$ & 9 & $2.56^{* *}$ & $90.98^{* *}$ & $1.41^{* *}$ & $0.407^{* *}$ \\
Error & 48 & 0.22 & 5.05 & 0.0030 & 0.0037 \\
C.V. (\%) & 0.48 & 2.53 & 1.41 & 1.64 \\
\hline${ }^{* *}$ Significant at 0.01 probability level & & & \\
\hline
\end{tabular}

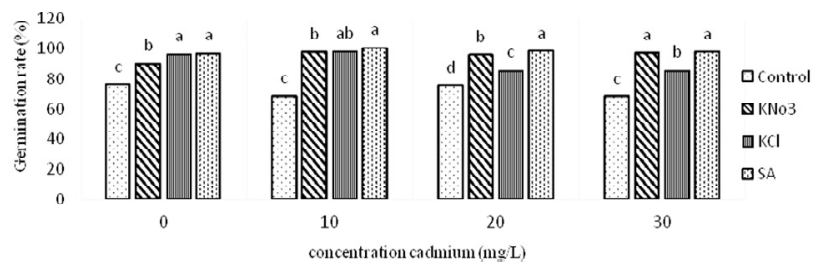

Fig. 2. Germination rate of unprimed (UPS) and primed (PS) fenugreek seedlings (Trigonella foenum-graecum L.) under different $\mathrm{Cd}$ concentrations

Germination rate was measured in unprimed seeds and when seeds were primed by $100 \mathrm{mg} / \mathrm{L} \mathrm{SA}$ and $-1 \mathrm{MPa}^{\mathrm{KNO}}$ and $\mathrm{KCl}$ solution for 24 hours. The unprimed seeds were used as the control. Means with similar letters resulted in no significant different $(\mathrm{p} \leq 0.05)$ based on LSD test.

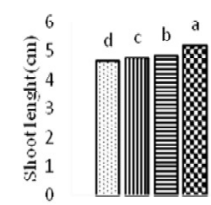

0

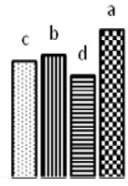

10

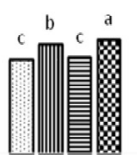

20

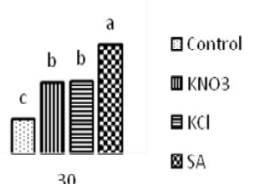

Fig. 3. Shoot length of unprimed (UPS) and primed (PS) seedling of fenugreek (Trigonella foenum-graecum L.) under different $\mathrm{Cd}$ concentrations

Shoot length was measured in unprimed seeds and when seeds were primed by $100 \mathrm{mg} / \mathrm{L} \mathrm{SA}$ and $-1 \mathrm{MPa}^{\mathrm{KNO}}{ }_{3}$ and $\mathrm{KCl}$ solution for 24 hours. The unprimed seeds were used as the control. Means with similar letters were not significantly different $(\mathrm{p} \leq 0.05)$ based on LSD test

negative effect on germination percentage compared to control treatment. Exposure to 20 and $30 \mathrm{mg} / \mathrm{L}$ of cadmium, $\mathrm{KNO}_{3}$ and $\mathrm{KCl}$ solutions resulted in no significant effect, but the values obtained were located in higher level than control treatment (Fig. 1).

\section{Germination rate}

There was a significant $(\mathrm{p}<0.01)$ effect of priming treatments on the germination rate (GR). Treated seeds in all cadmium concentrations had higher germination rate than the control. At 30 $\mathrm{mg} / \mathrm{L}$ of cadmium, germination rate was increased by $43.51 \%$, $42.7 \%$ and $26.26 \%$ with salicylic acid, potassium nitrate and potassium chloride compared to control, respectively. The maximum and minimum GR were observed for the primed seeds with SA and control, respectively. There was no significant difference between KCL and SA solution for GR in 0 and $10 \mathrm{mg} / \mathrm{L}$ cadmium. However, $\mathrm{KNO}_{3}$ and $\mathrm{SA}$ solution had no significant difference for $\mathrm{GR}$ in $30 \mathrm{mg} / \mathrm{L}$ cadmium. Seeds primed using $\mathrm{KNO}_{3}$ showed higher germination rate than $\mathrm{KCl}$ treatment, at 20 and $30 \mathrm{mg} / \mathrm{L}$ cadmium concentrations. Seeds exposed to $10 \mathrm{mg} / \mathrm{L}$ cadmium had no significant differences between them, but $\mathrm{KNO}_{3}$ soluble was lower than $\mathrm{KCl}$ soluble in cadmium concentration $0 \mathrm{mg} / \mathrm{L}$ (Fig. 2).

\section{Shoot length}

Interaction between salicylic acid and cadmium was significant for root and shoot length (Table 1). In all concentrations of cadmium, the greatest shoot length was obtained with SA primed seeds and the lowest shoot length was obtained within the control treatment. However, control treatment was not significantly different with $\mathrm{KCl}$ treatment under $20 \mathrm{mg} / \mathrm{L}$ cadmium. $\mathrm{KNO}_{3}$ and $\mathrm{KCl}$ treatments lead to shoot length increase compared to control treatment, except of shoot length for the treatment with $10 \mathrm{mg} / \mathrm{L}$ $\mathrm{Cd}$ in $\mathrm{KCl}$ solution which was lower than the control treatment. In all concentrations, there were significant differences among SA and 


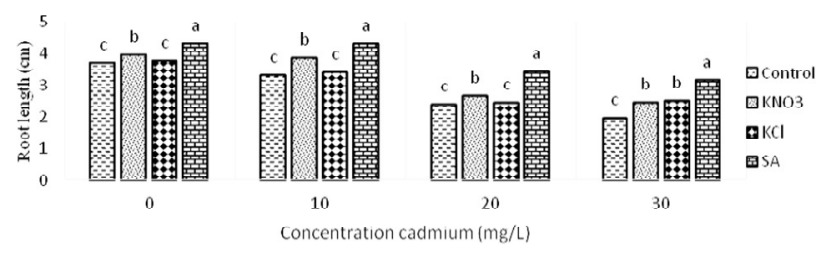

Fig. 4. Root length of unprimed (UPS) and primed (PS) fenugreek seedlings (Trigonella foenum-graecum L.) under different $\mathrm{Cd}$ concentrations

Root length was measured in unprimed seeds and when seeds were primed by 100 $\mathrm{mg} / \mathrm{L} \mathrm{SA}$ and - $1 \mathrm{MPa} \mathrm{KNO}_{3}$ and $\mathrm{KCl}$ solution for 24 hours. The unprimed seeds were used as the control. Means with similar letters were not significantly different $(\mathrm{p} \leq 0.05)$ based on LSD test.

other treatments for shoot length (Fig. 3). Exposed to 10 and 20 $\mathrm{mg} / \mathrm{L} \mathrm{Cd}$, treated seeds with potassium nitrate showed a better shoot length development than those subjected to potassium chloride treatment. In 10 and $20 \mathrm{mg} / \mathrm{L}$ cadmium, the shoot length in case of $\mathrm{KCl}$ treatment was shorter than the control (Fig. 3). Thus, in control group $(0 \mathrm{mg} / \mathrm{L}$ of $\mathrm{Cd}) \mathrm{KCl}$ solution was located in a higher level than the treatment of $\mathrm{KNO}_{3}$. Finally, at a concentration of $30 \mathrm{mg} / \mathrm{L}$ of $\mathrm{Cd}$, there was no significant difference between halopriming treatments $\left(\mathrm{KCl}\right.$ and $\left.\mathrm{KNO}_{3}\right)$. Shoot growth decreased more than root growth in $30 \mathrm{mg} / \mathrm{L}$ cadmium. Exposed to $30 \mathrm{mg} / \mathrm{L}$ of cadmium, the shoot length increased by 214.16, 100 and $109.16 \%$ with salicylic acid, potassium nitrate and potassium chloride, respectively, in comparison with the control. This indicated the shoot length was strongly influenced by priming treatments and it increased more than other germination parameters. Also, salicylic acid proved to be the most effective among priming treatments.

\section{Root length}

Seed priming treatments showed different effects on the root length. It decreased significantly with the increase of cadmium level as compared to the control treatment. The highest root length (RL) was obtained from seeds primed with SA treatment, which indicated that SA pretreatment increased cadmium tolerance in fenugreek seeds. Lowest RL was attained from control in all concentrations of cadmium. There was no significant effect in the concentration of 0,10 and $20 \mathrm{mg} / \mathrm{L}$ cadmium for $\mathrm{KCl}$ treatment. $\mathrm{KNO}_{3}$ treatment in all concentrations of cadmium had most of root length than of control. Significant effects were observed between SA treatment and other treatments in all cadmium concentrations (Fig. 4). Salicylic acid, potassium nitrate and potassium chloride increased the root length by $61.85 \%, 24.74 \%$ and $41.23 \%$, respectively, at a $30 \mathrm{mg} / \mathrm{L}$ cadmium concentration. Highly significant effect was observed between any of the treatments and control, while at concentrations of 0,10 and $20 \mathrm{mg} / \mathrm{L}$ cadmium root length was not significantly affected compared with control, in the treatment of $\mathrm{KCl}$ (Fig. 4). Exposed to 0, 10 and $20 \mathrm{mg} / \mathrm{L}$ of Cd, seeds primed by $\mathrm{KNO}_{3}$ treatment showed better root length development than $\mathrm{KCl}$ treatment. However, there was no significant effect between halopriming $\left(\mathrm{KCl}\right.$ and $\mathrm{KNO}_{3}$ ) treatments, at $30 \mathrm{mg} / \mathrm{L} \mathrm{Cd}$ concentration (Fig. 4).

\section{Shoot dry weight}

Analysis of variance in this experiment showed that seed priming, cadmium concentration and interaction between priming and cadmium concentration had significant effects $(\mathrm{p} \geq$ 0.01 ) on the shoot dry weight, root dry weight and vigor index (Table 2). In primed and unprimed seeds, shoot dry weight

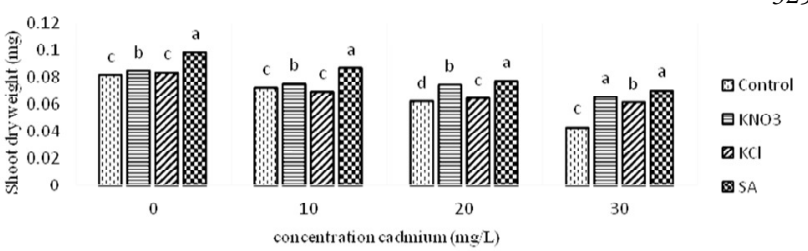

Fig. 5. Shoot dry weight of unprimed (UPS) and primed (PS) seedling of fenugreek (Trigonella foenum-graecum L.) under different $\mathrm{Cd}$ concentrations

Shoot dry weight was measured in unprimed seeds and when seeds were primed by $100 \mathrm{mg} / \mathrm{L} \mathrm{SA}$ and $-1 \mathrm{MPa} \mathrm{KNO}_{3}$ and $\mathrm{KCl}$ solution for $24 \mathrm{~h}$. The unprimed seeds were used as the control. Means with similar letters were not significantly different $(\mathrm{p} \leq 0.05)$ based on LSD test.

Table 2. Analysis of variance (mean square) for effects of seed priming on, root dry weight, shoot dry weight and vigor index of fenugreek under different cadmium concentrations

\begin{tabular}{ccccc}
\hline $\begin{array}{c}\text { Source of } \\
\text { variance }\end{array}$ & df & $\begin{array}{c}\text { Shoot dry } \\
\text { weight }\end{array}$ & $\begin{array}{c}\text { Root dry } \\
\text { weight }\end{array}$ & Vigor index \\
\hline $\begin{array}{c}\text { Seed priming } \\
(\mathrm{P})\end{array}$ & 3 & $0.0008^{* *}$ & $0.0000^{* *} 4$ & $331799^{* *}$ \\
$\begin{array}{c}\text { Cadmium } \\
(\mathrm{Cd})\end{array}$ & 3 & $0.0022^{* *}$ & $0.0002^{* *}$ & $85054^{* *}$ \\
$\mathrm{P} \times \mathrm{Cd}$ & 9 & $0.00008^{* *}$ & $0.00001^{* *}$ & $4236^{* *}$ \\
Error & 48 & 0.0000008 & 0.0000006 & 32.40 \\
C.V $(\%)$ & & 1.27 & 4.89 & 1.53 \\
\hline${ }^{* *}$ Significant at 0.01 probability level & & \\
\hline
\end{tabular}

decreased significantly with the increased cadmium concentration compared to the control (Fig. 5). Salicylic acid, potassium nitrate and potassium chloride increased the shoot dry weight with $62.79 \%, 51.16 \%$ and $41.86 \%$, respectively, at a concentration of $30 \mathrm{mg} / \mathrm{L}$ of cadmium. Seeds treated with 100 $\mathrm{mg} / \mathrm{L}$ of SA produced maximum shoot dry weight compared to other treatments. However, $\mathrm{KNO}_{3}$ and SA treatments had no significant effect at the concentration of $30 \mathrm{mg} / \mathrm{L}$ cadmium. The lowest shoot dry weight was observed in control treatment, in all concentrations of cadmium. At $\mathrm{KNO}_{3}$ and $\mathrm{KCl}$ treatments, shoot dry weight was more improved than control, in all cadmium concentrations, except at the 0 and $10 \mathrm{mg} / \mathrm{L}$ concentrations that, had no significant difference between control and $\mathrm{KCl}$ treatments (Fig. 5). At all cadmium levels, soluble $\mathrm{KNO}_{3}$ showed greater shoot dry weight than $\mathrm{KCl}$ treatment.

\section{Root dry weight}

Root dry weight decreased significantly with the increased of cadmium levels as compared to the control (Table 2). According to the results in Fig. 5, at all cadmium concentrations, maximum root dry weight was achieved from seeds primed with $100 \mathrm{mg} / \mathrm{L}$ SA, so that it had significant effect compared with control and the rest of the treatments. Minimum dry weight of root was observed in seeds primed with $\mathrm{KCl}$ at the $30 \mathrm{mg} / \mathrm{L}$ cadmium level. $\mathrm{KNO}_{3}$ and $\mathrm{KCl}$ treatments had no significant effect than control, while the data for the concentration of $20 \mathrm{mg} / \mathrm{L}$ cadmium showed that root dry weight was higher than the control (Fig. 6). Salicylic acid, potassium nitrate and potassium chloride increased the root dry weight by $100 \%, 30 \%$ and $50 \%$, in cadmium concentration of $30 \mathrm{mg} / \mathrm{L}$. (Fig. 6). Exposed to 20 $\mathrm{mg} / \mathrm{L}$ of cadmium, $\mathrm{KNO}_{3}$ treatment showed higher root dry 
326

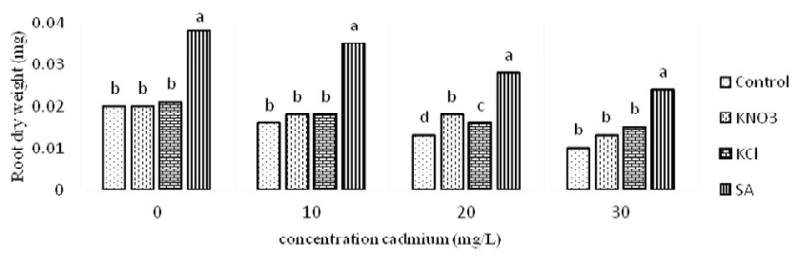

Fig. 6. Root dry weight of unprimed (UPS) and primed (PS) seedling of fenugreek (Trigonella foenum-graecum L.) under different $\mathrm{Cd}$ concentrations

Root dry weight was measured in unprimed seeds and when seeds were primed by $100 \mathrm{mg} / \mathrm{L} \mathrm{SA}$ and $-1 \mathrm{MPa} \mathrm{KNO}_{3}$ and $\mathrm{KCl}$ solution for $24 \mathrm{~h}$. The unprimed seeds were used as the control. Means with similar letters were not significant different $(\mathrm{p} \leq 0.05)$ based on LSD test.

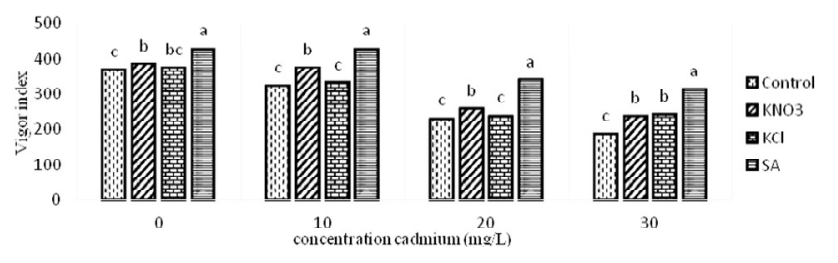

Fig. 7. Vigor index of unprimed (UPS) and primed (PS) seedling of fenugreek (Trigonella foenum-graecum L.) under different $\mathrm{Cd}$ concentrations

Vigor index was measured in unprimed seeds and when seeds were primed by 100 $\mathrm{mg} / \mathrm{L} \mathrm{SA}$ and $-1 \mathrm{MPa} \mathrm{KNO}_{3}$ and $\mathrm{KCl}$ solution for $24 \mathrm{~h}$. The unprimed seeds were used as the control. Means with similar letters were not significantly different $(\mathrm{p} \leq 0.05)$ based on LSD test.

weight than $\mathrm{KCl}$ treatment. However, there was no significant difference between $\mathrm{KNO}_{3}$ and $\mathrm{KCl}$ treatments in $10,30 \mathrm{mg} / \mathrm{L}$ of $\mathrm{Cd}$ and control group $(0 \mathrm{mg} / \mathrm{L}$ of $\mathrm{Cd})$ (Fig. 6).

\section{Vigorindex}

The maximum seedlings' vigor index was obtained in seeds primed with $100 \mathrm{mg} / \mathrm{L} \mathrm{SA}$ solution (Fig. 7), while the minimum value was observed in the control treatment with $30 \mathrm{mg} / \mathrm{L}$ cadmium. In all concentrations of cadmium, seedlings' vigor of SA showed more significant effects than other treatments. There was no significant difference between $\mathrm{KCl}$ solution and control treatment in all cadmium concentrations, except in the case of $30 \mathrm{mg} / \mathrm{L}$ of cadmium, where seeds primed with $\mathrm{KCl}$ treatment showed higher vigor index compared to control. At all cadmium concentrations, $\mathrm{KNO}_{3}$ treatment was located in higher level than $\mathrm{KCl}$ treatment, even though no significant effect was noted between them in $30 \mathrm{mg} / \mathrm{L}$ of $\mathrm{Cd}$ and control treatment $(0 \mathrm{mg} / \mathrm{L}$ of Cd) (Fig. 7$)$.

Improvement of vigor index in salicylic acid treatment resulted by same effects of the root length and germination percentages, however in potassium nitrate and potassium chloride treatment, root length was more effective than germination percentage (Fig. 1 and Fig. 4).

\section{Discussion}

The abnormalities of mitosis directly affected the cell division and growth rate, which showed marked symptoms of $\mathrm{Cd}$ toxicity, such as the inhibition of root elongation and morphological change. The Cd concentration that caused significant inhibition for shoot growth was much higher than that for root growth. Although Cd had no significant effects on seed germination, radicle and shoot growth were markedly inhibited by $\mathrm{Cd}$ (He et al., 2008). In other words, shoot growth proved to be more sensitive to cadmium stress. The reduction in growth could be a consequence of the $\mathrm{Cd}$ interference with a number of metabolic processes associated with normal development such as photosynthetic pigments production, membrane lipid composition, water uptake and mineral nutrition that would result in deficiency in essential elements and ultimately reduction in biomass production (Ammar et al., 2008).

Seed priming is a pre-sowing strategy for influencing seed germination and seedlings' development by modulating pre-germination metabolic activity prior to emergence of the radicle and generally enhancing germination rate and plant performance (Bradford, 1986). According to the current results, most of cadmium's toxic effects were observed on shoot length reduction as this parameter was more affected by priming treatments than the other parameters, so that salicylic acid, potassium nitrate and potassium chloride increased the shoot length with $214.16 \%, 100 \%$ and $109.16 \%$, respectively. However, these values were lower in the other parameters.

All treatments compared to the control resulted in a higher germination rate. These findings are in agreement with the results reported by (Demir and Mavi, 2004) who proved that salt priming can increase watermelon emergence. Farooq et al. (2007) noticed that halopriming with $\mathrm{KCl}$ improved germination and emergence in rice. Also, Farooq et al. (2006) reported that seed priming with $\mathrm{KCl}$ or $\mathrm{CaCl}_{2}$ improved the rate of germination, the length of shoot and root in rice seedling. Treated seeds of two celery varieties with $\mathrm{KNO}_{3}$ and $\mathrm{KCl}$ showed that the germination rate has increased, compared to the control (Perez-Garcia et al., 1995); the highest germination rate was recorded in $\mathrm{KNO}_{3}$ and SA treatments. Amjad et al. (2007) reported $\mathrm{KNO}_{3}$ to be better than other treatments by decreasing germination time to $50 \%$. It is plausible that $\mathrm{KNO}_{3}$ positive effect might be due to its role in influencing the permeability of the membranes, which ultimately leads to activation of enzymes involved in protein synthesis and carbohydrate metabolism (Preece and Read, 1993). Moreover, it plays role in formation of protoplasm and new cells, as well as encourages plant elongation. Also, potassium is a major essential element required for physiological mechanisms of plant growth (Aisha et al., 2007). Increase in shoot and radicle length might be due to induction of metabolic activates in embryo as a result of seed priming (Wahid et al., 2008).

However, some results show that the decrease of germination index in seeds primed with $\mathrm{KNO}_{3}$ at high levels might be due to toxic effects of solution on the embryo (Giri and Schillinger, 2003). According to Frett et al. (1991) using inorganic salts for the preparation of osmotic solution, due to osmotic damage to cell membranes and changes of enzyme that effect on germination, seeds can be harmed. The hereby study testing did not show such effects.

The application of $-0.3 \mathrm{MPa}$ of $\mathrm{KNO}_{3}$ increased the germination index compared to control. The experiment of Ramzan et al. (2010) have also led to an increase in the concentration of potassium nitrate that resulted in reduced 
germination percentage of gladiola plants, while at low concentrations germination was improved; this may be because high salt concentrations caused enhancement of cell death and reduced improvement of germination indices (Nascimento, 2003). However, greater efficiency of osmohardening with $\mathrm{KCl}$ is possibly related to the osmotic advantage that both $\mathrm{K}^{+}$and $\mathrm{Ca}^{2+}$ have in improving cell water saturation, and that they act as co-factors in the activities of numerous enzymes.

Salicylic acid could form a complex with Cd that may provide $\mathrm{Cd}$ tolerance (Choudhury and Panda, 2004). One of the important roles of SA in inducing resistance to various environmental stresses is manifested by its ability to express genes that code for pathogenesis-related proteins or defense-related enzymes (Merkouropoulos et al., 1999). The SA pretreatment alleviates Cd toxicity in barley (Metwally et al., 2003) and maize plants (Krantev et al., 2008). Significant decline in root length and dry weight was observed in SA free roots. The SA priming resulted in the increase of root length and dry weight. Reducing the effects of stress is explained by the fact that salicylic acid enhances some of plant hormones, such as auxin and cytokinin (Shakirova et al., 2003), while reducing ion leakage from the plant cells and decreasing accumulation of toxic ions in plants (Borsani et al., 2001). Salicylic acid through the development of anti-stress reactions such as the accumulation of proline, improves the growth of seedlings after the elimination of stress (Shakirova et al., 2003). Salicylic acid enhances germination parameters because of the protective action in the presence of heavy metals, leading to the stability of cell membrane (Mishra and Choudhuri, 1999). Changes in hormone balance (Shakirova et al., 2003) and cadmium ions become inactive (Metwally et al., 2003), aiming for removal of this metal from metabolic processes and reduction of its toxicity in spite of increasing concentrations. There are reports showing that seed priming permits early DNA replication, increases RNA and protein synthesis, enhances embryo growth, repairs deteriorated seed parts and reduces leakage of metabolites (McDonald, 2000). This technique helped seedlings grow in stress conditions (Ashraf and Foolad, 2005).

\section{Conclusions}

After long-term exposure to cadmium, roots became mucilaginous, browning and decomposing; reduction of shoots and root elongation can occur as well. Cd was found to inhibit lateral root formation, while the main fenugreek root became brown, rigid and twisted. In $30 \mathrm{mg} / \mathrm{L}$ of cadmium concentration, shoot growth decreased more than root growth and salicylic acid, potassium nitrate and potassium chloride increased the shoot length with 214.2, 100 and $109.2 \%$, respectively compared to the control. This indicated that shoot length was strongly influenced by the treatments and increased more than other germination parameters, while salicylic acid had the most protective effect. Highest germination indices were observed in seeds primed with SA under various stress levels, because SA could form a complex with cadmium that may provide $\mathrm{Cd}$ tolerance. Because the protective action of SA in the presence of heavy metals which led to the stability of cell membrane, changes in hormone balance and inactivity of cadmium ions could be observed. Even though $\mathrm{KNO}_{3}$ and
$\mathrm{KCl}$ treatments may also cause enhancement of germination indices, since the treatment with salicylic acid showed better results for all germination indices, it can be concluded that salicylic acid is the best seed priming agent to reduce the toxicity of cadmium in fields exposed to Cd-polluted water.

\section{References}

Aisha AH, Rizk FA, Shaheen AM, Abdel-Mouty MM (2007). Onion plant growth, bulb yield and its physical and chemical properties as affected by organic and natural fertilization. Research Journal of Agriculture and Biological Sciences 3(5):380-388.

Alvarez ME (2000). Salicylic acid in the machinery of hypersensitive cell death and disease resistance. Plant Molecular Biology 44:429-442.

Ammar WB, Nouairi I, Zarrouk M, Ghorbel MH, Jemal F (2008). Antioxidative response to cadmium in roots and leaves of tomato plants. Biologia Plantarum 52(4):727731.

Amjad M, Ziaf K, Iqbal Q, Ahmad I, Riaz MA, Saqib ZA (2007). Effect of seed priming on seed vigor and salt tolerance in hot pepper. Pakistan Journal of Agricultural Sciences 44:408-416.

Ashraf M, Foolad MR (2005). Pre-sowing seed treatment-a shotgun approach to improve germination, plant growth and crop yield under saline and non-saline conditions. Advances in Agronomy 88:223-271.

Astolfi S, Zuchi S, Chiani C, Passera C (2003). In vivo and in vitro effects of cadmium on $\mathrm{H}+\mathrm{ATP}$ ase activity of plasma membrane vesicles from oat (Avena sativa L.) roots. Journal of Plant Physiology 160(4):387-393.

Borsani O, Valpuesta V, Botella MA (2001). Evidence for a role of salicylic acid in the oxidative damage generated by $\mathrm{NaCl}$ and osmotic stress in Arabidopsis seedlings. Plant Physiology 126:1024-1030.

Bradford KJ (1986). Manipulation of seed water relations via osmotic priming to improve germination under stress conditions. Horticultural Science 21:1105-1112.

Choudhury S, Panda SK (2004). Role of salicylic acid in regulating cadmium induced oxidative stress in (Oryza sativa L.) roots. Bulgarian Journal of Plant Physiology 30:95-110.

Demir I, Mavi K (2004). The effect of priming on seedling emergence of differentially matured watermelon (Citrullus lanatus (Thump). Matsum and Nakai) seeds. Scientia Horticulturae 102(4):467-473.

D'Souza L, Devi P, Shridhar DMP, Naik CG (2008). Use of fourier transform infrared (FTIR) spectroscopy to study cadmium-induced changes in Padina Tetrastromatica (Hauck). Analytical Chemistry Insights 3:135-143.

Eidi A, Eidi M, Sokhteh M (2007). Effect of fenugreek (Trigonella foenum-graecum L.) seeds on serum parameters in normal and streptozotocin-induced diabetic rats. Nutrition Research 27:728-733. 
328

El-Araby M, Hegazi AZ (2004). Response of tomato seed to hydro- and osmo-priming and possible relation of some antioxidant enzymes and endogenous polyamine fractions.Egyptian Journal of Biology 6:81-93.

Farooq M, Barsa SMA, Ur-Rahman H (2006). Seed priming enhances emergence, yield, and quality of direct seeded rice. Crop Management and Physiology 12:42-47.

Farooq M, Basra SMA, Wahid A, Ahmad N (2010). Changes in nutrient homeostasis and reserves metabolism during rice seed priming: Cosequences for seedling emergence and growth. Agricultural Sciences in China 9(2):191-198.

Farooq M, Basra SMA, Ahmad N (2007). Improving the performance of transplanted rice by seed priming. Plant Growth Regulation 51:129-137.

Frett JJ, Pill WG, Moreau DC (1991). A comparison of priming agents for tomato and asparagus seed. Horticultural Science 26:1158-1159.

Giri GS, Schilinger WF (2003). Seed priming winter wheat for germination, emergence and yield. Crop Science 43:2135-2141.

He JY, Ren YF, Zhu C, Jiang DA (2008). Effects of cadmium stress on seed germination, seedling growth and seed amylase activities in rice (Oryza sativa). Rice Science 15(4):319-325.

Ikic I, Maric Evic M, Tomasovic S, Gunjaca J, Satovic Z, Sarcevic H (2012). The effect of germination temperature on seed dormancy in Croatian-grown winter wheats. Euphytica 188(1):25-34.

ISTA (International Seed Testing Association) (2009). International Rules for Seed Testing. International Seed Testing Association, Bassersdorf, Switzerland.

Kalsa KK, Abebie B (2012). Influence of seed priming on seed germination and vigor traits of Vicia villosa spp. dasycarpa (Ten.). African Journal of Agricultural Research 7(21):3202-3208.

Kaviarasan S, Naik G, Gangabhagirathi H, Anuradha RCV, Priyadarsini KI (2007). In vitro studies on antiradical and antioxidant activities of fenugreek (Trigonella foenumgracum) seeds. Food Chemistery 103(1):31-37.

Kotowski F (1926). Temperature relation to germination of vegetable seed. Proceeding of the American Society Horticulture Science 23:179-184.

Krantev A, Yordanova R, Janda T, Szalai G, Popova L (2008). Treatment with salicylic acid decreases the effect of cadmium on photosynthesis in maize plants. Journal of Plant Physiology 165:920-931.

Krystofova O, Shestivska V, Galiova M, Novotny K, Kaiser J, Zehnalek J, Babula P, Opatrilova, R, Adam V, Kizek R (2009). Sunflower plants as bioindicators of environmental pollution with lead (II) ions. Sensors 9:5040-5058.

La Rocca N, Andreoli C, Giacometti GM, Rascio N, Moro I (2009). Responses of the Antarctic microalga Koliella antartica (Trebouxiophyceae, Chlorophyta) to cadmium contamination. Photosynthetica 47:471-479.
Liu JG, Li KQ, Xu JK, Liang J, Lu X, Yang J, Zhu Q (2003). Interaction of $\mathrm{Cd}$ and five mineral nutrients for uptake and accumulation in different rice cultivars and genotype. Field Crops Research 83(3):271-281.

Liu J, Cao C, Wong M, Zhang Z, Chai Y (2010). Variations between rice cultivars in iron and manganese plaque on roots and the relation with plant cadmium uptake. Journal of Environmental Sciences 22(7):1067-1072.

McDonald MB (2000). Seed priming. In: Black M, Bewley JD (Eds), Seed Technology and Biological Basis. Sheffield Academic Press England pp 287-325.

Merkouropoulos G, Barnett DC, Shirasat AH (1999). The Arabidopsis extension gene is developmentally regulated, is induced by wounding, methyl jasmonate, abscisic and salicylic acid, and codes for a protein with unusual motifs. Planta 208(2):212-219.

Metwally A, Finkemeier I, Georgi M, Dietz KJ (2003). Salicylic acid alleviates the cadmium toxicity in barley seedlings. Plant Physiology 132:272-281.

Mishra A, Choudhuri MA (1999). Effects of salicylic acid on heavy metalinduced membrane degradation mediated by lipoxygenase in rice. Biologia Plantarum 42:409-415.

Mishra S, Srivastava S, Tripathi RD, Govindarajan R, Kuriakose SV, Parasad MNV (2006). Phytochelatin synthesis and response of antioxidant during cadmium stress in Bacopamonnieri L. Plant Physiology and Biochemestry 44(1):25-37.

Mudipalli A (2008). Metals (micro nutrients or toxicants) and global health. Indian Journal of Medical Research 128(4):331-334.

Mwale SS, Hamusimbi C, Mwansa K (2003). Germination, emergence and growth of sunflower (Helianthus annuus L.) in response to osmotic seed priming. Seed Science and Technology 31:199-206.

Nascimento WM (2003). Musk melon seed germination and seedling development in response to seed priming. Scientica Agricola 60(1):71-75.

Neamatollahi E, Bannayan M, Darban AS, Ghanbari A (2009). Hydropriming and osmopriming effects on cumin (Cuminum Cyminum L.) seeds germination. World Academy of Science Engineering and Technology 57:526529.

Perez-Garcia F, Pita GM, Gonzalez-Benito ME, Iriondo JM (1995). Effect of light, temperature and seed priming on germination of celery seed (Apium graveolens L.). Seed Science and Technology 23:377-383.

Petropoulos GA (2002). Fenugreek. In: Petropoulos GA (Ed). The genus Trigonella. Taylor and Francis, London and New York.

Popova LP, Maslenkova LT, Yordanova RY, Ivanova A, Krantev AP, Szalai G, Janda T (2009). Exogenous treatment with salicylic acid attenuates cadmium toxicity in pea seedlings. Plant Physiology Biochemistr 47:224-231.

Preece JE, Read PE (1993). Mineral nutrition. In: The biology of Horticulture. John Wiley and Sons Publisher pp 257-259. 
Rascio N, Navari-Izzo F (2011). Heavy metal hyperaccumulating plants: How and why do they do it? And what makes them so interesting? Plant Science 180(2):169-181.

Rama MP, Alonso JA, López CH, Vaamonde ET (2002). Cadmium removal by living cells of the marine microalga Tetraselmis suecica. Bioresource Technology 84(3):265270.

Ramzan A, Hafez IA, Ahmad, T, Abbasi NA (2010). Effect of priming with potassium nitrate and dehusking on seed germination of Gladiolus (Gladiojus alatus). Pakistan Journal of Botany 42(1):247-258.

Siebert ET, Richardson MD (2002). Effects of osmopriming on bermudagrass germination and establishment. Horticultural Studies AAES Research Series 506:36-38.

Shakirova FM, Sakhabutdinova AR, Bezrukova MV, Fatkhutdinova RA, Fatkhutdinova DR (2003). Changes in hormonal status of wheat seedling induced by salicylic acid and salinity. Plant Science 164(3):317-322.
Tissa S, Darren T, Eric B, Kinsley D (2000). Acetyl salicylic acid (aspirin) and salicylic acid induce multiple stress tolerance in bean and tomato plants. Plant Growth Regulation 30:157-161.

Wahid A, Noreen A, Basra SMA, Gelani S, Farooq M (2008). Priming-induced metabolic changes in sunflower (Helianthus annuus) achenes improve germination and seedling growth. Botanical Studies 49:343-350.

Wang HY, Chen CL, Sung JM (2003). Both warm water soaking and solid priming treatments enhance antioxidation of bitter gourd seeds germinated at sub-optimal temperature. Seed Science and Technology 31:47-56. 